\title{
«ПОЗНАВАТЕЛЬНОЕ РАЗВИТИЕ», «РЕЧЕВОЕ РАЗВИТИЕ», «СОЦИАЛЬНО-КОММУНИКАТИВНОЕ РАЗВИТИЕ» ДЛЯ ДЕТЕЙ ВТОРОЙ МЛАДШЕЙ ГРУППЫ НА ТЕМУ «МАТЕМАТИЧЕСКОЕ ПУТЕШЕСТВИЕ»
}

\author{
Шихшабекова Залина Магомедкамиловна \\ МБДОУ д/с «Белочка» \\ г. Тарко-Сале
}

Аннотация: Оригинальность раскрытия темы заключалась в использовании на всем протяжении занятия ИКТ беседы с героями сказок и оказание им помощи.

Проблемные ситуации решались за счет использования на занятии словесных, сюрпризных, наглядных, практических, проблемно-поисковых методов, а также таких видов деятельности, как игровая, коммуникативная, двигательная, познавательно-исследовательская.

Занятие было построено в виде путешествия по сказкам, где нас ждали герои сказок, и были созданы проблемные ситуации, используя при этом наглядные картинки, дидактические игры. В каждом моменте занятия использовались в работе с детьми вопросы поискового характера, создавались проблемные ситуации, вопросы на сообразительность и логическое мышление - все это способствовало эффективности занятия, повышению познавательной и мыслительной деятельности. Все моменты занятия логичны и последовательны, подчинены одной теме. Во время занятия отрабатывались навыки поведения детей (внимательно слушать задания, проявлять выдержку). Поведение детей на занятии регулировала и направляла, поддерживая у детей интерес к занятию на протяжении всего времени.

Abstract: The originality of the disclosure of the topic consisted in the use of ICT throughout the lesson - this is a conversation with the heroes of fairy tales and showing them help.

Problematic situations were solved through the use of verbal, surprise, visual, practical, problem-searching methods, as well as such types of activities as play, communicative, motor, cognitive - research.

The lesson was built in the form of a journey through fairy tales, where the heroes of fairy tales were waiting for us, and problem situations were created, using visual pictures, didactic games. At every moment of the lesson, questions of a 
search nature were used in working with children, problem situations were created, questions for quick wits and logical thinking - all this contributed to the effectiveness of the lesson, and to increase cognitive and mental activity. All moments of the lesson are logical and consistent, subordinate to one topic. During the lesson, children's behavior skills were practiced (listen carefully to the assignments, show restraint).

The behavior of the children in the lesson was regulated and directed, keeping the children interested in the lesson throughout the entire time.

\section{Lesson content:}

At the first stop, I used a surprise moment, when the animated characters from the fairy tale "Teremok" talked with the children and we helped the heroes build a house, completing the task from Kuizener's sticks, where they fixed both counting and color, geometric shapes of a triangle, a square, and of course the ability to work according to the scheme. They also consolidated the concepts: high, low, slightly lower with stumps when looking for a ray.

After the first stop, I decided to use health-preserving technologies: gymnastics for the eyes to consolidate the prevention of fatigue, strengthening the eye muscles, relieving tension, and general improvement of the visual apparatus.

The second stop is ours: "Three Bears", here I used a surprise moment with animated characters from a fairy tale, where a problem situation was created to collect apples of three colors: red, yellow, green, in baskets of the same color. In this task, we fixed the colors: red, yellow, green.

During the relaxation after the second stop, I smoothly moved on to another surprise moment with a wonderful bag, where the children guessed by touch what was in it, by this I developed fine motor skills and developed tactile perception.

At the third station, a chanterelle from a fairy tale: "The Fox and the Crane" was waiting for us, we helped her to collect the beads that she accidentally torn, here we fixed the sequence of the arrangement of geometric figures, relying on the diagram.

I believe that the goals and objectives set by me have been achieved.

\section{Содержание занятия:}

На первой остановке использовался сюрпризный момент, когда анимационные персонажи из сказки «Теремок» разговаривали с детьми и мы помогали героям строить домик, выполняя задание из палочек Кюизенера, где закрепляли и счет и цвет, геометрические фигуры треугольник, квадрат, и 
конечно же умение работать по схеме. Также закрепляли понятия: высокий, низкий, чуть ниже с пенечками, когда искали лучик.

После первой остановки использовались здоровьесберегающие технологии: гимнастику для глаз, чтобы закрепить предупреждение утомления, укрепление глазных мышц, снятие напряжения, общее оздоровление зрительного аппарата.

Вторая остановка: «Три медведя», здесь использовался сюрпризный момент с анимационными персонажами из сказки, где была создана проблемная ситуация собрать яблочки трех цветов: красные, желтые, зеленые, в корзины такого же цвета. В этом задании мы закрепляли цвета: красный, желтый, зеленый.

Во время релаксации после второй остановки я плавно перешла на еще один сюрпризный момент с чудесным мешочком, где дети на ощупь отгадывали, что в нем находится, этим я развивала мелкую моторику, и развивала тактильное восприятие.

На третьей станции нас ожидала лисичка из сказки: «Лиса и журавль», мы помогали ей собрать бусы, которые она случайно порвала, здесь мы закрепляли последовательность расположения геометрических фигур, опираясь на схему.

Считаю, что поставленные мною цели и задачи были достигнуты.

Возрастная группа: вторая младшая.

Форма совместной деятельности: интегрированная НОД.

Форма организации: групповая.

Интеграция областей: «Познавательное развитие», «Речевое развитие», «Социально-коммуникативное развитие».

Предварительная работа: дидактические игры «Цвет и форма», «Найди такой же», «На что похоже?», «Построй такой же» (палочки Кюизенера), «Чудесный мешочек»;

театрализованная деятельность (сказки «Три медведя», «Теремок»).

Виды деятельности: игровая, коммуникативная, двигательная, познавательно-исследовательская.

Методы обучения: словесный, наглядный, практический, проблемнопоисковый.

Учебно-методический комплект 
Наглядные: карточки, презентация.

Мультимедийные: презентация, анимационная физминутка.

Литература: сказки «Три медведя», «Теремок».

Музыкальные: релаксация - звуки природы.

Оборудование:

демонстрационные: солнечные лучики (из желтого картона), костюм Маши; макеты деревьев, искусственные цветы; 4 корзины (1 большая, 3 одинаковые по размеру, но разные по цвету - красная, желтая, зеленая), яблоки зеленые, желтые, красные по 4 шт.; «Чудесный мешочек» (пластмассовая чашка, резиновая кукла, резиновый мячик, пластмассовый кубик, деревянная ложка, металлическая машинка, мягкая игрушка зайчика, матрешка); 3 пенёчка разной высоты.

раздаточные: наборы палочек Кюизенера по количеству детей, карточки - схемы на каждого ребенка с изображением домика из палочек Кюзинера, карточки-схемы с изображением бус из бусинок разного цвета, эмблемы с изображением солнышка на каждого ребенка.

Средства ТСО: проектор, экран для проецирования.

Место проведения: групповое помещение или музыкальный зал.

Цель: Формировать элементарные математические представления, закрепить ранее полученные знания.

\section{Задачи:}

\section{Обучающие задачи:}

* продолжать формирование мыслительных операций (анализа, сравнения, обобщения, классификации);

* закрепить знание геометрических фигур (треугольник, круг, квадрат);

закрепить понятия много, один, по одному, понимать вопрос «Сколько?»;

* закрепить умения группировать предметы по цвету, называть цвета в речи;

закрепить умение определять величину предметов, результат сравнения отражать в речи: большой, маленький, поменьше; находить высокий и низкий предметы.

\section{Развивающие задачи:}

продолжать развивать связную речь детей, коммуникативные качества;

* развивать внимание, память, воображение, наблюдательность, мыслительную активность, мелкую и общую моторику. 


\section{Воспитательные задачи:}

воспитывать стремление оказывать помощь другим, которые оказались в трудной ситуации;

* воспитывать дружеские взаимоотношения между детьми, привычку заниматься сообща;

воспитывать интерес и доброжелательное отношение к окружающему миру.

\section{Ход занятия:}

Воспитатель в костюме Маши из мультфильма «Маша и медведь» взволнованно встречает детей.

\section{Маша:}

- Здравствуйте, ребята, а вы узнали меня (ответы детей)

\section{Маша:}

(если дети не ответят правильно) - Я же Машенька из мультфильма «Маша и медведь», я очень рада вас видеть, давайте знакомиться (дети называют свои имена). Посмотрите, у нас сегодня замечательные гости, давайте с ними поздороваемся (дети здороваются).

\section{Организационный момент.}

Воспитатель собирает детей в круг:

Встанем все красиво в круг

И поднимем ручки,

После за руки возьмемся

И друг другу улыбнемся.

Маша: - Посмотрите ребята, какой красивый у нас получился круг. А на что он похож?

Дети: - На круг, пуговицу, колесо, мячик, руль, обруч, солнышко.

Маша: - Ой, солнышко, я же вспомнила, ребята, что я шла от своего друга Медведя домой и заблудилась, поэтому я хотела попросить солнышко, чтобы оно помогло мне найти дорогу домой (на экране появляется грустное солнылико).

Солнышко: - Здравствуйте, ребята.

Маша: - Здравствуй, солнышко, я как раз к тебе шла, что бы ты мне помог найти и осветить дорогу домой, а то я заблудилась.

Солнышко: - Я бы радо тебе помочь Машенька, но не могу, дело в том, что когда я гуляло над волшебным сказочным лесом, потеряло свои лучики и теперь не могу светить ярко. 
Маша: - Как потеряла?

Солнышко: - Да и такое бывает, я даже не заметила, как потеряла. Ребята вы мне не поможете найти мои лучики, ведь только тогда я смогу помочь Маше найти дорогу домой.

Маша: - Ребята, вы поможете мне и солнышко найти лучики.

Дети: - Да.

Маша: - А как же нам помочь Солнышко, где же искать лучики?

Дети: - В волшебном сказочном лесу.

Маша: - На чем же можно туда отправиться?

Дети: - На машине, самолете, пароходе, паровозе.

Маша: - А можно отправиться еще на волшебном паровозике. Вы готовы, ребята?

Дети: - Да.

Маша: - Тогда занимайте места в вагончиках, и мы свами отправляемся в волшебный сказочный лес искать лучики нашего солнышко. Все заняли места, тогда поехали.

(дети едут на импровизированном паровозике).

Маша: «Под весёлый стук колёс мчит по рельсам паровоз: Дым, пуская на лету, паровоз гудит: ту-ту!».

Маша: - А вот и первая станция, интересно как же она называется, давайте посмотрим, ребята (на экране появляется картинка с изображением сломанного теремка и героев).

Маша: - Ребята, герои какой сказки нас встречают? (ответы детей).

Маша: - А давайте с вами назовем их.

Дети: - Мышка, лягушка, зайчик, лисичка, волк.

Маша: - Скажите, сколько зверей жило в теремке сначала? (ни одного).

- Сколько их стало потом? (много).

- Сколько здесь мышек? (одна).

- А сколько лягушек в теремке? (Одна).

- Правильно. И мышка одна, и лисичка одна, а всех вместе... много.

- Ребята, посмотрите ведь у них сломан теремок, а кто же его сломал?

Дети: - Медведь.

Маша: - Как же мы можем им помочь? (ответы детей: нарисовать дом, построчть из кубиков, вылепить из пластилина). 
- А давайте с вами поможем зверюшкам построить новый теремок, подойдите, пожалуйста, к столу и посмотрите. Что же это в коробочках лежит?

Дети: - Палочки.

Маша: обращает внимание на мольберт

- Ребята, давайте посмотрим, что есть у домика (крыша, стены, окошко).

- Какой формы стена дома? (квадратной).

- Какой формы крыша? (треугольной).

- Посмотрите, какого цвета стены, пол и потолок у домика (синего).

- Маша, а какого цвета крыша (красного ивета).

- Петя, какого цвета окошки? (белого).

- Молодцы, давайте подойдем к столам и будем строить, возьмите палочки того же цвета и положите на части домика (воспитатель помогает детям наводящими вопросами - какого цвета палочку нужно взять для стен? для крыши? для окон? сколько палочек синего ивета, белого ивета? они одинаковые по длине? и т.д.).

Маша: - Вот какой замечательный дом получился, посмотрите, звери вас благодарят за красивый теремок (на экране появляется картинка $c$ изображением построенного теремка и героями они благодарят детей за красивый теремок, и спрашивают у них, куда путь держат).

Зайчик: - Я видел лучик, когда гулял по лесу, он вон за тем самым низким пенечком, посмотрите ребята.

Маша: - Ребята, смотрите, перед нами пеньки. Сколько их? (3) (Хоровые и индивидуальные ответы). Ребята, а по высоте пеньки одинаковые или разные? (Разные). Да, все пеньки разной высоты. Этот пенёк какой? (Низкий). А этот? (Повыме). А этот пенёк? (Высокий). Правильно! (Имя), найди самый низкий пенёк. (дети за низким пенечком находят лучик).

Дети: - Нашли, вот наш лучик.

Проводится физминутка для глаз:

Лучик детям улыбнись,

Лучик вверх, лучик вниз.

Вправо, влево повернись

Вокруг солнца обернись.

Маша: - Молодцы, ребята, умнички, но нам надо поспешить лучики остальные найти.

(Дети благодарят героев сказки теремок и отправляются дальше). 
Маша: - Вторая станция: «Три медведя» (на экране появляются три медведя).

Михаил Потапыч: (с экрана)

- Здравствуйте, ребята, куда путь держите.

Дети и Маша: - Мы помогаем нашему солнышко найти лучики, оно случайно их растеряло в волшебном сказочном лесу.

Настасья Петровна: ( и собирали яблочки, наша семья очень любит их, то нашли в лесу ваш лучик, и положили его на дно корзины, а после собрали яблочки. Но вот, ребята, незадача, собрали мы все яблоки в одну корзину, а дома собирались разложить их в три корзины, дело в том, что Мхаил Потапыч любит зеленые яблоки, и его яблочки надо положить в зеленую корзину, моя же корзина красная, и я люблю красные яблочки, а наш Мишутка любит желтые яблочки, у него корзина желтая. Если вы разложите яблочки по корзинам, то сможете взять свой лучик.

Маша: - Давайте, ребята, с вами разложим яблочки поскорее, чтобы найти еще один лучик (дети выполняют задание, раскладывают яблоки по цвету: желтые в желтую корзину, красные - в красную, зеленые - в зеленую; и находят на дне корзины лучик).

Маша: - Ураааа, мы нашли еще один лучик.

(Дети с Машей благодарят Медведей и отправляются дальше на своем волшебном паровозике).

Дети приезжают на волшебную поляну

Маша: - Ребята, посмотрите как красиво на этой волшебной поляне, давайте с вами остановимся здесь. Послушайте, как красиво поют птички, давайте с вами присядем и закроем глазки, послушаем, как дует ветерок, шелестит трава, нам так хорошо здесь, да, ребята.

Маша: - Ой, смотрите, ребята, а что это у нас за тем деревом находиться?

Дети совместно с Машей идут смотреть, что это?

Дети: - Это мешочек.

Маша: - А давайте с вами отгадаем, что же находиться в мешочке, для этого нам нужно просунуть свою ручку в мешочек и отгадать, что же там лежит.

(дети по очереди просовывают свои ручки в мешочек и угадывают на ощупь, что там находиться). 
Дети: - Это кубик, мячик, шарик, куколка, машинка, кружечка и т.д.

Маша: - Вы просто молодцы, ребята, умнички. Но, по-моему тут еще что о есть, можно я посмотрю, ребята?

Дети: - Да

(Маша на omynь пытается отгадать, что в мешочке лежит, но не угадывает).

Маша: - Ребята помоги те мне, пожалуйста, а то я что-то не могу понять, что это?

(дети просовывают руку и достают оттуда 2 лучика).

Маша: - Смотрите, ребята, это же лучики, а сколько их здесь, (дети считают): 2 лучика.

Маша: - Правильно ребята, давайте с вами заберем наши лучики, и отправимся с вами дальше в наше путешествие, вы согласны ребята?

Дети: - Да.

Маша: - Занимайте места в вагончиках и поехали: ту-ту-ту-ту-ту чухчухчух-чух-чух.

Маша: - Ой смотрите, ребята, а кто это нас встречает (на экране появляется лисииа).

Дети: - Лиса.

Лиса: - Куда путь держите ребята?

Маша с ребятами: - Мы помогаем нашему солнышко найти лучики, оно случайно их растеряло в волшебном сказочном лесу. Вы не находили лучик?

Лиса: - Ааaа, я вспомнила, ребята, когда я шла в гости к своему другу Журавлю, то нашла в лесу ваш лучик и подобрала ее, я вам его обязательно отдам, но сначала не смогли ли бы вы и мне помочь.

Маша: - А что случилось?

Лиса: - Дело в том, что я случайно порвала свои любимые бусы, и хотела бы, чтобы вы мне помогли собрать их вот по этой фотографии.

Маша: - Ну что, ребята, поможем лисичке?

Дети: - Да.

Маша: - Посмотрите внимательно на фото бус. Какого цвета круги мы здесь видим?

Дети: - Красного, желтого, синего.

Маша: - А какого они размера? (большие). Запомните их очередность. 
Затем убирается образеи, детям предлагают вспомнить и повторить тот же узор. Далее воспитатель предлагает детям продолжить узор в заданной последовательности (бусы выкладываем из Блоков Дьенеша).

Маша: - Молодцы, ребята.

Лиса: - Спасибо вам, ребята, такие красивые и замечательные получились бусы. За то, что вы помогли мне, я вам даю, как и обещала, лучик, который нашла. Лучик этот находится вон в коробочке на столе.

(Дети и Маша достают лучик, благодарят лису, а лиса благодарит детей за помощь).

Маша: - Ну что, ребята, нашли мы свами все лучики нашего солнышко, давайте с вами вернем их солнышко.

(Маша возвращает лучики, солнышко начинает светить ярко).

Солнышко: - Спасибо вам, ребята, теперь я смогу и Маше указать дорогу домой.

Маша: - Урааааа, наконец-то я тоже попаду домой.

Солнышко: - А вам, ребята, за то, что вы мне помогли, я вам приготовила подарки и дарю частичку своего тепла (солнышкко дарит эмблемы солнца каждому ребенку).

\section{3.Итог.}

Воспитатель: - Спасибо вам, мои дорогие ребята. Вы сегодня мне и солнышко очень помогли, а вам понравилось наше путешествие? В гостях у каких сказок мы побывали? Какие задания вам понравилось выполнять?

Ну что ж, давайте мы с солнышко вас проводим в группу, занимайте места на нашем с вами волшебном паровозике, и мы свами поедем в вашу группу, а потом солнышко мне поможет добраться домой, все заняли мести в вагончиках?

Дети: - Да.

Маша: - Тогда поехали: ту-ту-ту-ту-ту чух-чухчух-чухчух.

\section{Заключение:}

Итог занятия был подведен, дети были рады помочь солнышко, и получили за это частичку его тепла. Материал детьми усвоен.

Считаем, что поставленные программные задачи в ходе занятия были решены. 